\title{
Use of Space in the Physical Separation of the Bourgeoisie and the Working Class in "The Exterminating Angel” (1962) and "The Swamp" (2001)
}

\author{
Matthew Berg ${ }^{1}$ \\ Montclair State University, College of Humanities and Social Science
}

Received 30 March 2018 - Revised 10 June 2018 • Accepted 15 July 2018

\begin{abstract}
The struggle between the bourgeoisie and the working class is reflected in the filmography of many countries, including that of Spain and Argentina, specifically through the films El Ángel Exterminador (The Exterminating Angel) (1962), directed by Luis Buñuel, and La Ciénaga (The Swamp) (2001), directed by Lucrecia Martel. Each director utilizes interior and exterior space to demonstrate the difference between the working and bourgeoise classes within their films. As stated by Charles Shiro Tashiro in his observations of The Go-Between, the set design and narrative of cinema are intertwined in such a way that the setting of a film is essential to the successful delivery of the message and context of said film. This comparative study will focus on how Buñuel's and Martel's aforementioned films follow a similar pattern in 3 aspects of this use of space: the use of large estates with the mansion in The Exterminating Angel and the La Madrágona house in The Swamp to create a physical barrier that is representative of the metaphorical barrier between socioeconomic classes, the use of interior space to create a sense of entrapment within the confines of the bourgeoisie, and the sense of barrenness created by the grandeur of the bourgeois space.
\end{abstract}

Keywords: Spanish film, Latin American film, class, Spanish language, gender studies.

\section{Introduction}

Beginning in the $20^{\text {th }}$ century, a unique phenomenon occurred: the birth and growth of a quite powerful middle class. In addition, a new struggle was born between the working class and this new class. This struggle is reflected in the filmography of many countries, including that of Spain and Argentina- specifically through the films El Angel Exterminador (The Exterminating Angel) (1962), directed by Luis Buñuel, and La Ciénaga (The Swamp) (2001), directed by Lucrecia Martel. Despite the differences in cultural origin, time, and gender perspective, each film utilizes interior and exterior space to demonstrate the difference between the working and bourgeoise classes. For example, as observed by Charles Shiro Tashiro in The GoBetween, the set design and narrative of cinema are intertwined in such a way that the setting of a film is essential to the successful delivery of its message and context. Therefore, this comparative study focuses on how Buñuel's and Martel's aforementioned films follow a similar pattern in three

\footnotetext{
${ }^{1}$ The author is MA student at the Montclair State University.
}

(C) Authors. Terms and conditions of Creative Commons Attribution 4.0 International (CC BY 4.0) apply. Correspondence: Matthew Berg, 21 Lakeview Court, Cherry Hill, NJ, USA 08003. E-mail: bergm2@montclair.edu. 
spatial ways: the use of large estates, particularly the mansion in The Exterminating Angel and the La Mandrágora house in The Swamp, which creates a physical barrier representative of the metaphorical barrier between socioeconomic classes; the use of interior space to create a sense of entrapment within the confines of the bourgeoisie; and the use of smallness, and therefore the insignificance, created by the grandeur of the bourgeois space.

- The Exterminating Angel and The Swamp demonstrate similar patterns in the utilization of space to create a physical divide representative of a metaphorical divide between the bourgeoisie and the working class.

- Both directors reinforce the divide between these two classes through large estates.

- The emptiness within the bourgeois space in both films becomes a metaphor for the emptiness of bourgeois values.

\section{Creation of a physical barrier}

According to Tashiro in his article "'Reading' Design in the Go-Between”, the elements within set design possess multiple meanings, including narrative and symbolic meanings (Tashiro, 1993). Tashiro states that the character Miriam's dress serves the narrative purpose of expressing the desire of the main character Leo, while also showcasing Miriam's femininity and her social status (Tashiro, 1993). Both directors manifest this idea that Tashiro presents through the estates within each film. These estates not only represent the wealth of the characters, but also represent a more profound meaning by creating a physical barrier that represents the metaphorical separation between socioeconomic classes. While it is true that the estate in The Exterminating Angel serves as a way of identifying and showing the wealth of the bourgeoisie, Buñuel also uses this space of the mansion to take away the wealth that his bourgeois characters exude via the entrapment of said characters within the mansion. In his article Buñuel's social close-up: An entomological gaze on El ángel exterminador (The exterminating angel) (1962), James Ramey compares Buñuel's treatment of his characters to that of ants being transferred to a glass case for observation (Ramey, 1962: 330). When the bourgeois characters are trapped in the main room of the mansion, nobody outside of the building can enter. This isolates both the bourgeois characters within the mansion as well as the members of the working class outside of the mansion within their respective classes. In his article Suspensión del sentido y repetición en El ángel exterminador (Buñuel, 1962), Pedro Poyato explains that this phenomenon complies with the idea that the isolation of the characters is entirely irrational (Poyato, 2011), and that Buñel utilizes the space outside of and within the mansion to achieve this irrationality. Outside observers only observe from the window, as though they were entomologists observing a group of ants, while the mansion is the case that traps them within. Thus, when the little boy, Johnny, an outside observer, tries to enter the mansion, he is unable. From the very first night the lines between colony and the other are drawn. From there, within the main room, the characters create their own new colony, accepting and trapping any person that is inside the building, including a member of the working class. Julio, a waiter, chooses not to escape with the other employees. Because of this, although he is part of the working class, he is trapped within the main room due to his dedication to the service of the bourgeois, thus further reiterating the new colony and being locked out of the space created by his own class outside of the mansion.

Moreover, Martel clearly demonstrates the difference between Tali and her bourgeois cousin, Mecha, through the differences between their homes. La Mandrágora, Mecha's estate, is huge even when housing six people. The vast size of the space is apparent during scenes that take place within La Madrágora. For example, each time that Tali and her family want to visit Mecha, they must pass through a gate and later drive to the door. They cannot viably walk from the gate to the mansion through the massive woods that shield La Mandrágora from the rest of the world. 
This not only gives the audience a sense of the estate's great size but also said gate is an example of the manifestation of the separation between Tali and Mecha. Each time that Tali wants to visit her cousin, she must physically cross the barrier between them before entering La Madrágora. In addition, within the scenes outside of the mansion on Mecha's property, above all of the scenes near the pool such as the first scene, the mountains and forest are visible in the background. This creates a connection between the members of Mecha's family and the nature surrounding their property, suggesting their ownership of it. Moreover, there are many scenes where Mecha's and Tali's children freely explore the aforementioned nature. While the children find animals, they never find other people. Therefore, it appears that the natural space beyond the mansion belongs to Mecha and her bourgeois family, that everything belongs to Mecha and her family, as there are never any other people seen on or around La Mandrágora.

On the other hand, Tali's home is quite humble. Where Mecha has a large pool and acres of land and forest, Tali has a tiny closed-in garden, with no more than a few potted plants. Additionally, while La Mandrágora has multiple floors, Tali's home is comprised of one floor only. One also feels the difference in space that each cousin possesses through the size of their families. Each family has six members, but inside Tali's home it seems that there is not sufficient space to house all six people. When her daughters run in the garden where Tali and Luci are already standing, one feels uncomfortable and the space seems suffocating. As the girls dash back and forth through the tiny closed in space, it appears that they could make Tali, who is standing on a ladder, fall at any moment. In contrast, when Mecha's and Tali's sons are exploring the forest near Mecha's house and they discover an ox, they appear as small as ants underneath the height of the trees and the size of the ox.

Within Tali's house there is another physical manifestation inside the garden of the barrier between classes: the ladder. Martel uses the imagery of a ladder, and how one physically climbs it, to symbolize the socioeconomic climb of the classes. Tali and Luci are seen multiple times near or directly on climbing the ladder. Throughout the entire film Tali becomes closer and closer with her bourgeois cousin, and because of this she distances herself from her working-class life. This emotional and mental distance is made visible when Tali cannot stand to be in her husband's workroom and when she plans a trip to Bolivia with Mecha without their families. These are strong indications of Tali's desire to become closer to the bourgeoisie. To reinforce the restrictions that prevent this climbing of the socioeconomic ladder, at the end of the movie, when Lucio tries to climb the ladder in the garden, he falls and, while his death is not seen, it is implied that he subsequently dies. This ladder serves as a reminder of the nearly impossible and arduous task that is crossing the lines drawn between classes. In his review of The Swamp, Pablo Brescia mentions the circular nature of Luci falling from the ladder, comparing it to the introduction of the film where Mecha falls on the shards of her glass (Brescia, 2002). This creates an interesting juxtaposition of the fate of Mecha alongside that of Luci. Martel physically manifests the consequences of promoting the values of the bourgeoisie through the falling of Mecha onto those shards of the life of excess she leads. However, while Mecha is able to recover from her fall, those that are merit into her ways, like Luci, do not have the same privilege. Thus, Martel exemplifies one more privilege that the bourgeoisie has over their working-class counterparts: the means to survive.

Similarly, Martel reinforces the futility of Tali's efforts to rise above her economic status via the result of her and Mecha's trip to Bolivia. Martel uses Bolivia as a physical representation of an equalizer between the two cousins and the circumstances that divide them and makes it clear that, even though both parties wish to cross the threshold between their classes, this is an impossible feat. Martel also demonstrates that resistance to change is not only present within the bourgeoisie, but also other members of the working class. Tali's husband scoffs at the idea of his wife travelling to Bolivia alone with Mecha, remarking that it would be too dangerous for the two women to travel alone to Bolivia. Therefore, even the members of Tali's own class are 
working against her process of crossing the threshold into a more bourgeois life. A similar pattern occurs with the depiction of the virgin throughout the film. Throughout the movie, the TV screens shown are discussing sightings of the virgin and interviews with people who have claimed to see her. The Swamp ends with Momi returning to the poolside, a gunshot ringing in the background, stating that she went to where the virgin appeared and saw nothing. The virgin, a symbol of hope and a religious figure throughout the film, does not appear for Momi, a member of the bourgeoisie. The place where the virgin appears represents a promised land of salvation for Momi from her bourgeois upbringing. Martel is depriving her bourgeois characters of said salvation from their lifestyle and of their nature.

Both films use mirrors as a physical manifestation of the bourgeoisie's egotistical obsession. In The Exterminating Angel, the mirror serves as a reminder of the past life of the characters. When each character is in front of it, they seem to temporarily forego their current insanities and instead, switch their focus to their physical appearance - an important attribute that any member of the bourgeoisie must maintain. In The Swamp, Mecha's husband, Gregorio, is consistently shown in front of a mirror, combing his hair, demonstrating the aforementioned obsession with appearances. Mecha shows a similar fixation with her appearance when she falls on the shards of her glass. Even though she is bleeding, she refuses to get in the car to go to the hospital until she changes into prettier clothing. Additionally, José, Mecha and Gregorio's son, finds himself in front of the mirror, most notably before he goes out dancing. When José steps in front of the mirror before going out, it solidifies his return to his bourgeois family, as he exhibits the same egotistical behavior as his father at the beginning of the film: he is in front of the mirror drying and fixing his hair, obsessed with his own appearance. Martel solidifies this transformation with the following sequence of events where José entertains his younger sisters and cousins, Tali, and Mecha, appearing almost father like in his goofy demeanor and through his dancing with all of the women as the lead. This solidifies also the passing down of the vain values of the bourgeoisie from one generation to another.

\section{Use of interior space}

Furthermore, the use of interior space in both film creates a sense of entrapment within the confines of the bourgeoisie. Space within buildings in the films are often seen as a means of separating characters from others. In The Swamp, one of the main characters, Momi, is trapped within the heteronormative and restrictive confines of the bourgeois world in which she lives. As Ana Forcinto mentions in her article Lo Invisible y Lo Invivible: El Nuevo Cine Argentino de Mujeres y Sus Huellas Acústicas, the audience always sees Momi's desire when she observes one of the maids, Isabel (Forcinto 40). When Momi looks at her when Isabel is with her boyfriend in the bathroom or when she observes her when they sleep in the same bed, Momi always, in the words of Forcinto, is spying and desiring (Forcinto 40). But Momi is also always hidden, always watching when Isabel turns her back or is in another room. Martel puts Momi in an isolated space apart from Isabel, forcing her to interiorize her desire for Isabel by separating Momi from any outlet she could have for that desire. This demonstrates the solitude of living with this desire under the control of the heteronormative confines that restrict the growth of any non-heterosexual desire. Through her observations, Momi also reverses the roles set in The Exterminating Angel where the working class observes the bourgeoisie. Momi watches Isabel as though she were an ant, attempting to learn about life through the interactions that Isabel has with the world outside $L a$ Madrágora and attempting to see if she can comprehend the desire that she feels while watching. Later in the film Martel reinforces the restrictive nature of the gender norms imposed by the bourgeoisie through the contrast of interactions between the opposite sexes within both families. After showering, Verónica enters a room where José is laying down. Once she removes the towel covering her chest, José immediately turns around, so he cannot see her. The camera then immediately cuts to Tali's husband bathing one of their little daughters in a sink where any 
member of the family could walk in. Martel, through this contrast of images, demonstrates a contrast between the gender norms within the two families. Even though José is Verónica's brother, he is not comfortable inhabiting the same space as her once she disrobes due to the strict role he has been shown for women by bourgeois society: as sex objects. Moreover, Verónica turns her back to the screen while she disrobes so that her chest is not visible while we are shown the bare chest of the little girl. Martel creates distance between the viewer and the nudity of the more mature girl because of the societal standards that dictate what is appropriate within both scenarios.

Similarly, alcohol becomes another manifestation of a decadence that traps the bourgeoisie. Brescia cites Gregorio and Mecha as figures of excess given their affinity for alcohol (Brescia, 2002). In nearly every scene, Brescia points out, the two of them have alcohol in their hands or Mecha is asking the employees for "hielito" (a little bit of ice) or "alguito" (a little something), euphemisms for wine (Brescia, 2002), a symbol of the excess needed by the bourgeois characters. The constant need for alcohol is a physical manifestation of a need of the bourgeois to numb themselves to that which goes on around them, trapping them in their own worlds and isolating them from the outside. The alcohol even traps Mecha physically by sending her to the hospital when she falls on the shards of her broken glass and consequently damning her to bed rest within the mansion. La Mandrágora itself thus serves as a prision for Mecha, who does not leave the house after going to the hospital. Momi makes an explicit comparison between Mecha and her mother, who never left the house, saying "you're never going to leave the house, just like grandmother". Thus, the space within the house becomes a manner of isolating Mecha, forcing her to pay the price for her life of excess. Furthermore, alcohol becomes the poison that seals Tali's fate. When she returns to visit Mecha, Mecha offers her "alguito fresco" (a little cool something), which Tali initially declines but inevitably falls into Mecha's contagious tendencies, ensuring her later downfall into a desire for a bourgeois life. This image of a death of Tali's old working-class values is reinforced by the gunshots heard outside at the beginning of the scene, indicating the killing of those values by Mecha.

Martel shows the effect of the bourgeoisie on those that surround them in the workingclass interior space through Tali and her family. During a visit to Mecha, a few of Tali's children are waiting in the car. Sounds are heard outside the car, including dogs barking and a few gunshots. Eventually Mecha's husband knocks on the car window and the children hide. Using the space within the car, Martel isolates the two groups by their social class. Moreover, Martel goes so far as to trap Tali and her children outside of the bourgeoisie life, specifically through the aforementioned garden. In the garden, the sounds of dogs barking can also be heard at all times. At one point, upon hearing the barking behind the garden wall, Luci asks his mother if the wall will break due to the dogs' knocking into it. Tali assures her son that the dogs cannot break the wall since it is a strong wall. The walls, which isolate the family from the outside dogs, is a metaphor for the barrier between the bourgeois and the working class. While the walls of this divide protect the family from falling victim to the life of excess of the bourgeoisies, it nonetheless isolates them. The conversation is also indicative of the passing of this separation between classes from one generation to another, reinforcing it. Additionally, Tali herself demonstrates the futility of trying to break through this physical/metaphorical wall by hammering a nail into it. Even though Tali tries to break through this barrier to her cousin, much like the nail in the wall she cannot quite pierce it entirely.

Buñuel uses the closet within the main room as a symbol for physical isolation. The closet serves as an escape from the confines of the bourgeoisie. Additionally, it shares a connection with the area inside the main room with the piano, which will later in the film become a space for secrets between characters. The first night, Beatriz and Eduardo begin their affair behind the curtains in front of the piano. After, the two of them end their affair inside the closet when they commit suicide. The link between the closet and the curtains near the piano are observed in reverse 
in Lucía's case. She is the first one who discovers the closet. At the end of the entrapment of everyone within the main room, when Lucía realizes the escape route, she and Nobile appear from behind the curtains near the piano. As a result, Buñuel creates an image of Lucía opening a proverbial Pandora's box, which liberates all of the bad elements of the situation since, after unlocking the closet, everyone begins to deteriorate and forget the rules of politeness. However, much like Pandora being left with hope, Lucía is left with the solution.

Moreover, Buñuel uses the interior of the church as a means to isolate the bourgeoise once and for all. A key difference between the design of the main room of the mansion and the church is the lack of a space where one can separate oneself from the others in the church. While the main room has the closet and the area behind the curtains, there is no such space where one can hide or isolate oneself in the church. This isolation is essential to the creation of solution that allows the characters to escape. Without such an area where the characters are able to think outside of the expectations of the bourgeoisie, they are all destined to remain trapped. Furthermore, Buñuel creates a juxtaposition of the interior of the church, where the clergy and the bourgeois are trapped, with the pandemonium outside of the church where people, presumably members of the working class pictured outside the mansion earlier in the film, are being shot at. While the bourgeois do end the movie being trapped, Buñuel presents this as perhaps the better option, demonstrating that the alternative to being free from the confines of the bourgeoisie is instead, a world in chaos. In this way, Buñuel, along similar lines to Martel, presents the damage done to the bourgeois characters as a privilege compared to the fate of their proletariat counterparts.

\section{Bareness of the bourgeois space}

The grandeur of the bourgeois space pictured in both movies creates an environment that shows the emptiness that accompanies living as a member of the bourgeoisie. At the beginning of The Exterminating Angel, there is a scene that shows the servants preparing an empty mansion. Outside, all of the bourgeois characters are chatting, dwarfed under the height of the mansion in the background. Here, Buñuel compares the emptiness of the mansion to the life of the bourgeoisie. Additionally, the workers must be present to prepare this farce, emphasizing the fragility of bourgeois life. The same thing occurs when the bourgeois characters enter the mansion. Ramey draws attention to the floor, noting that "the marble floor upon which the guests enter is an ornate grey and white chessboard design" (Ramey 329). When, a few minutes later, the camera pans to the invitees in the entranceway, the invitees are shrunken, reducing them to a size similar to that of chess pieces. This image shows the lack of sense within bourgeois life, which is a complex game, and begins the complications that result in the entrapment of the invitees. Furthermore, when the bear enters The Exterminating Angel, one can feel the emptiness of the space that nobody occupies. When the bear enters, it is small, but it has a shadow that appears larger on the ceiling. This image, in addition to giving a strong sense of false largeness of the problems of the bourgeoisie, shows the huge amount of space that is not inhabited by anyone.

The same pattern is present in the size of La Mandrágora. Like Buñuel, Martel creates a contrast between the size of the bourgeois characters in the film and the place that they occupy, using a juxtaposition of different elements of space. At the beginning of the movie, when Mecha falls, trees are always seen in the background of the pool. Martel reminds the viewer that the grandeur constructed by the bourgeoisie pales in comparison to all that surrounds it. In addition, the camera pans inside that forest to some of the children hunting. Under the huge mass of trees, the children appear much tinier, similar to Buñuel's characters under the massiveness of the entrance in the mansion. Martel demonstrates something similar during the scene in which Mecha has to answer the phone when Mercedes calls José. When everyone, including the employees, are busy and Mecha must do something by herself, La Mandrágora becomes a gigantic space without 
any sense. Mecha stumbles from her room, screaming and confused, almost getting lost due to the sudden hugeness of her own home. However, when she calls for José, her voice sounds far away from José's room even though both of them are in the same house. This, combined with the huge size of the hallway that Mecha must cross in order to arrive at the phone, reiterates an image of largeness.

Finally, the phone becomes a physical manifestation of each character's ties to their class throughout the movie and a form of isolation between the characters, especially in relation to José. At the beginning of the film, when José is depicted in Buenos Aires with Mercedes, the older woman with whom he lives, he is usually on the phone with his family, indicating his lingering attachment to the bourgeois life he has left behind in La Ciénaga. This creates a barrier between José and Mercedes where anytime Mercedes is in the same room as José, they usually do not speak since he is on the phone with his family. Once José returns to La Ciénaga to visit his family, he is cut off from his life in Buenos Aires completely. Most of the time when the phone rings, it is Mercedes asking for José and José either ignores the call or the characters that answer the phone for him cannot locate him within the house. Even though his life in La Mandrágora is detrimental to him, comprised almost exclusively of him sleeping and getting into bar fights, José finds himself trapped in the mansion. The phone calls with his family at the beginning of the film suck José back into his bourgeois ways, and once he arrives, he no longer wants to return to his old life. Similarly, the phone serves as a means of alienating Mecha. As previously mentioned, when Mecha must answer the phone from her room, the house becomes an unknown maze to her. In this way, the phone alienates and disorients Mecha in her own home. The same phenomenon occurs later in the film when Mecha cannot figure out how to transfer a call to José's room. She is seen struggling to find the right button and accidentally putting Mercedes on speaker instead of transferring the call, unable to figure out what to do until José enters the room. The phone thus highlights Mecha's separation from the outside world and the technologies and culture within the world outside her room and her wine.

Martel and Buñuel manipulate the space within The Swamp and The Exterminating Angel to emphasize the division between socioeconomic classes in said films. Although the two movies are from different times and directors, both possess special elements which strengthen and demonstrate the severity of the separation between the bourgeoisie and the proletariat, a use of interior space to isolate the bourgeoisie, and utilize the grandeur of the bourgeois space to emphasize the emptiness of bourgeois life.

Acknowledgements

Dr. Raúl Galoppe, proofreading.

Fe Reyes, proofreading.

This research did not receive any specific grant from funding agencies in the public, commercial, or not-for-profit sectors.

References

Alatriste, G. (Producer) \& Buñuel, L. (Director). (1962) The exterminating angel [Motion Picture]. Mexico: Gustavo Alatriste.

Brescia, P. (2002). La ciénaga. Chasqui, 2, 152-155. 
Matthew Berg - Use of Space in the Physical Separation of the Bourgeoisie and the...

Forcinto, A. (2013). Lo invisible y lo invivible: El nuevo cine argentino de mujeres y sus Huellas acústicas. Chasqui, 1, 37-53.

Martins, L. (2013). En contra de contar historias. Cuerpos e imágenes hápticas en el cine argentino (Lisandro Alonso y Lucrecia Martel). Revista de Crítica Literaria Latinoamericana, 37(73), 401-420.

Poyato, P. (2011). Suspensión del sentido y repetición en El ángel exterminador (Buñuel, 1962). Fotocinema: Revista Científica De Cine Y Fotografía, 3, 3-16.

Ramey, J. (2016). Buñuel's social close-up: An entomological gaze on El ángel exterminador/The exterminating angel (1962). Studies in Spanish \& Latin American Cinemas. 13(3), 319-337.

Stantins, L. (Producer) \& Martel, L. (Director). (2001). The Swamp [Motion Picture]. Argentina, Spain, France: Cowboy Pictures.

Tashiro, C.S. (1993). "Reading” design in "The go-between". Cinema Journal, 33(1), 17-34. 